\title{
Qinyi Yang* \\ Emotional positioning in British news reports about Dover and Essex migrant tragedies: A corpus-based study
}

\author{
https://doi.org/10.1515/jwl-2020-0001
}

Received April 2, 2020; accepted May 10, 2021; published online October 27, 2021

\begin{abstract}
This article, based on the Appraisal System, investigates British journalists' different attitudes toward China and Vietnam in British news reports about the Dover migrant tragedy in 2000 and the Essex migrant tragedy in 2019. By analyzing affect resources in a newly built corpus with the help of UAM Corpus Tool 3.3, this study finds that more negative affect resources are used to portray China than those depicting Vietnam. British journalists manipulated emotions to emphasize that China, whether in 2000 or 2019, was a backward and underdeveloped country where citizens tried all means to escape to Britain. However, when British journalists found that the victims were Vietnamese instead of Chinese, they shifted attention to the pitiful Vietnamese families of the victims and tended to arouse readers' sympathy. The corpus findings highlight the ideological contradiction between Britain and China, reveal Britain's distrust of China's system, and suggest that the different comprehensive national powers of China and Vietnam have different impacts on Britain's international status, verifying that news discourse is permeated by ideology, politics, and economy.
\end{abstract}

Keywords: appraisal system; British newspapers; emotion; illegal immigration

\section{Introduction}

The news that 39 bodies were found inside a refrigerated lorry trailer in Essex, England on October 23rd, 2019 shocked the whole world. The initial statement by British police that "the victims were all Chinese nationals"1 was followed by plenty of media coverage regarding Chinese snakehead gang, disparities in development,

1 https://www.theguardian.com/uk-news/2019/oct/24/lorry-victims-were-trapped-beforereaching-belgian-coast-officials-say (accessed 25 January 2020).

*Corresponding author: Qinyi Yang, School of Foreign Languages, Shanghai Jiao Tong University, Shanghai, China, E-mail: 593319393@qq.com 
as well as human rights abuses in China. Later on, when more and more Vietnamese feared that their loved ones were among the dead, the police modified their previous remarks: "As our investigations continue, the picture may change regarding identification."2 After the British police confirmed on November 1st, 2019 that all victims were Vietnamese, journalists shifted their focus from China to Vietnam.

The event was reminiscent of another tragedy that happened in 2000 when 58 Chinese people were found dead in a lorry at Dover, England. With stereotypical image of Chinese migrants stored in mind, British journalists made up stories about Chinese migrants according to their own imagination.

Public attitudes toward immigration and the countries where the immigrants come from can be largely influenced by the attitudes expressed in news reports, as most of the British public had not been to China or Vietnam before the tragedies, or lacked direct contact with immigrants from China or Vietnam, and mainly depended on media to obtain information about the two tragedies and the two countries. As previous studies indicate, news media plays a significant role in shaping public perception of immigrants and the regions where they come from (Blinder 2015; Blinder and Allen 2016; Cheregi 2015; Gavin 2018; Igartua and Cheng 2009; McLaren et al. 2018).

Considering that the two migrant tragedies have caused extensive concern, we intend to investigate British journalists' different attitudes toward China and Vietnam in the British coverage of the two tragedies by applying Appraisal System (Martin and White 2005). Below are the research questions we attempt to answer:

(1) What attitudes were expressed toward China in the British news reports about the Dover tragedy?

(2) What attitudes were expressed toward China in the British news reports about the Essex tragedy when victims were suspected to be Chinese?

(3) What attitudes were expressed toward Vietnam in the British news reports about the Essex migrant tragedy when victims were believed to be Vietnamese?

(4) What similarities and differences can be found in the attitudes toward China and Vietnam in the British news reports about the two migrant tragedies?

In the rest of this article, a literature review of immigration is provided first, which is followed by the introduction of the newly built corpus as well as the analytical framework. Then, corpus findings are presented, summarized, and discussed. Finally, a conclusion is drawn.

2 https://www.warringtonguardian.co.uk/news/18192849.essex-lorry-deaths-thomas-joannamaher-released-police/ (accessed 25 January 2020). 


\section{Literature review}

Illegal immigration, concerned with illegal entry, illegal residence, and illegal employment, is an issue faced by a lot of countries, especially developed ones. Song (2008) compared the ways Germany and the UK treated and controlled illegal immigrants. He found that the UK put emphasis on border control when dealing with illegal immigration. He concluded in his paper that the immigration law in the UK was not as strict as that in Germany and that the Britain society was more inclusive of illegal immigrants. However, Düvell (2011) argues that the relevance of border controls for containing irregular migration is often exaggerated in the EU, and disproportionate attention is paid to irregular migration.

Economic factors play significant roles in shaping attitudes toward immigration. $\mathrm{Xu}$ (2018) examines how immigration policies have changed over time and points out that the domestic economic situation, the political stance of the ruling parties as well as religions are the factors that have influenced policymaking. It is revealed that welfare concerns play a more important role in determination of attitudes to further immigration than labor market concerns, and racial or cultural prejudice is also an important component to attitudes toward immigration (Dustmann and Preston 2007). Scholars suggested that anxiety about a national economic downturn increased opposition toward immigration. In addition, anxiety about taxes and generalized feelings about the major immigrant groups are significant determinants of restrictionist sentiment (Citrin et al. 1997). However, other scholars contended that "immigration policies have not been closely linked to economic considerations in general. Instead, they have been driven almost entirely by fears of deteriorating race relations" (Hatton and Price 2005: 165).

Evidence shows that the media has an impact on attitude formation, especially where "the public are dependent on coverage and have weak partisan predispositions" (Gavin 2018: 840). In other words, on many issues, people encounter relevant phenomena directly rather than through media. They try to understand events according to what they have experienced in their lives (Gamson and Modigliani 1989). However, on some big issues that people do not have direct experiences, they turn to other sources, especially media. This is called 'obtrusiveness hypothesis': in the realm of unobtrusive issues (those that cannot be directly observed by the public), the media have far more power in "setting the public's agenda" (McLaren et al. 2018: 3). Furthermore, media has the capacity to reinforce pre-existing attitudes (Gavin 2018). According to Igartua and Cheng (2009), crime growth frame stimulated more negative responses toward immigration, emphasized immigration as a problem, and generated a negative attitude toward immigration, etc. Cheregi (2015) found that when describing a Romanian migrant in Britain, British journalists presented his personal 
life as a threat to the British citizens, revealing that he was a drug user and had beaten his former girlfriend. By presenting his personal life, journalists created a negative image of a whole Romanian nation, influencing public opinions toward them. The image of immigrants was established through imagination most of the time since no individual can directly experience or apprehend the phenomenon of immigration as a whole and sources of information about immigration usually provide incomplete depictions of it (Blinder 2015). Blinder and Allen (2016) investigated how migrant groups were constructed in British national newspapers from 2010 to 2012 through corpus analysis, revealing that British national press stressed the issue of illegal status and depicted immigrants as law-violators. The corpus findings disclosed a divergence of media description from the real image of immigration. The authors suggested that media influence may lead to more negative attitudes and that by alienating migrants, media constructions may harm integration.

The political ideology of newspapers influences how newspapers cover immigration. Ideologies are the foundations of group attitudes and other beliefs and thus also control the biased personal mental models that underlie the production of ideological discourse (van Dijk 2006).

Emotion also plays a role in exerting impact on attitudes toward immigration. It is found that group cues have impact on opinion and political action by triggering emotions, especially anxiety (Brader et al. 2008). Scholars also found that affective processes shape how people make political judgments (Marcus et al. 2005). Huan (2017) employed Appraisal System to investigate what strategies Chinese and Australian journalists used to mobilize and mediate emotions in hard news reporting on risk events and revealed divergent stances undertaken by Chinese and Australian journalists.

To summarize, scholars have studied immigration by examining economic, political, racial, and emotional factors. In addition, media plays a significant role in shaping public attitudes toward big issues, such as immigration. Yet we noticed that studies on British journalists' different attitudes toward migrants from different countries (e.g. China and Vietnam) are insufficient. Therefore, this study attempts to investigate British journalists' different attitudes toward immigrants from China and Vietnam by examining emotion patterns presented in British newspapers.

\section{Data and methods}

This section introduces the data and methods used in this study. Firstly, the procedures of the data collection are introduced; secondly, the analytical framework is presented; thirdly, the details of annotating emotions are demonstrated. 


\subsection{Corpus construction}

To investigate the similarities and differences in the ways British journalists covered China and Vietnam in the Dover migrant tragedy in 2000 and the Essex migrant tragedy in 2019, a corpus of news reports about the two similar tragedies was constructed. The corpus comprises targeted news reports from The Guardian and The Times, which are respectively the influential left-wing and right-wing newspapers in Britain (Oxford Royale Academy 2016).

The corpus is comprised of three folders. The Dover- $\mathrm{C}$ folder contains news reports about the Dover tragedy where victims are Chinese and it captures news reports that contain all of the three keywords Dover, 58, and Chinese in the two newspapers from June 18, 2000 to August 18, 2000. The Essex-C folder contains news reports about the Essex tragedy when victims are suspected to be Chinese and it is comprised of news reports that contain both the two keywords Essex, 39, and at least one of the two terms China, Chinese in the two newspapers from October 23, 2019 to December 23, 2019. The Essex-V folder contains news reports about the Essex tragedy when victims are believed to be Vietnamese and it consists of news reports containing both the two keywords Essex, 39, and at least one of the two terms Vietnam, Vietnamese in the two newspapers from October 23, 2019 to December 23, 2019. The selection for the news reports in the Essex-C folder and Essex-V folder was manually inspected to ensure that the news reports in the Essex-C folder focused on Chinese migrants and those in the Essex- $V$ folder dealt with Vietnamese migrants. The summary of the corpus is presented in Table 1.

Table 1: Summary of the news corpus.

\begin{tabular}{llrrr}
\hline Folders & Newspaper & News texts & Word count & Total words \\
\hline Dover-C & The Guardian & 16 & 11,475 & 17,563 \\
& The Times & 10 & 6,088 & \\
Essex-C & The Guardian & 14 & 12,021 & 22,170 \\
& The Times & 12 & 10,149 & \\
Essex-V & The Guardian & 25 & 19,234 & 34,289 \\
& The Times & 26 & 15055 & \\
& & & &
\end{tabular}

News reports were found by searching the Factiva newspaper database. The identical articles were automatically excluded to ensure that only one copy of the same article was downloaded, and all of the articles were examined manually later to confirm that they are different from each other. It should be noted that news reports in this article only refer to news articles, excluding other genres such as 
opinion pieces or letters. In addition, news in brief and news that consist of no more than 200 words were excluded for lack of information. Irrelevant news and news in which the tragedy event was simply mentioned were also manually deleted from the corpus. All texts were encoded in UTF-8. Texts were cleaned with only file information (i.e. titles, authors, dates, word counts, publications, publishers) and the reports themselves left.

\subsection{Analytical framework}

This study adopts Appraisal System (Martin and White 2005) as the analytical framework. Appraisal is a system of interpersonal meaning. We negotiate our social relationships by using Appraisal resources, i.e. telling our listeners or readers how we feel about things and people (Martin and Rose 2007). There are three aspects of Appraisal System: attitudes, graduation (i.e. how attitudes are amplified), and engagement (i.e. resources of attitudes). Attitudes can be further divided into three semantic regions: the attitude concerned with people's feelings is called affect; the attitude related to people's character is known as judgement; and that associated with the value of things is appreciation (Martin and White 2005). Since this study focuses on emotions, affect system will be the specific analytical framework.

Affect is concerned with registering positive and negative feelings: happy or sad, confident or anxious, interested or bored. The conscious participant experiencing the feeling is called an Emoter, and the phenomenon responsible for the feeling a Trigger (Martin and White 2005). Affect can be classified into irrealis affect and realis affect. Irrealis affect deals with desiderative mental processes while realis affect is concerned with emotive mental processes. Dis/inclination is concerned with irrealis emotions (e.g. fear, desire), emotions that are triggered by events that have not yet happened (Huan 2017: 465). Realis affect can be grouped into three major sets: un/happiness, in/security, and dis/satisfaction. Un/happiness involves feelings such as misery, antipathy, cheer, and affection; in/security is concerned with emotions such as disquiet, surprise, confidence, and trust; while dis/satisfaction covers feelings like ennui, displeasure, interest,and pleasure (Martin and White 2005: 49-50). The affect system is displayed in Figure 1.

It should be noted that fear involves two levels of meaning according to the seventh edition of the Oxford Advanced Learner's Dictionary. One is "to be frightened of somebody or something or frightened of doing something" (Sally 2005: 561), falling into the category of dis/inclination; the other is "to feel that something 
affect $-\left[\begin{array}{l}\text { dis/inclination } \\ \text { un/happiness } \\ \text { in/security } \\ \text { dis/satisfaction }\end{array}\right.$

Figure 1: Affect system (Huan 2017: 465).

bad might have happened or might happen in the future” (Sally 2005: 561), falling into the category of in/security.

\subsection{Annotation procedures}

First, all of the affect resources were manually annotated with the aid of the UAM Corpus Tool 3.3. The emotion annotation was guided by the word list presented in Martin and White (2005) and Martin and Rose (2007). We only considered the emotions directly inscribed in texts while excluded indirect realizations in this study.

Using words and phrases as the measuring unit, we annotated each item in terms of emotions, emoters and triggers. Emoters were divided into the following 12 categories: power elites (including government officials and experts in Western countries, China, and Vietnam), ordinary citizens (of Western countries, China, and Vietnam), victims, families of the victims, other migrants (except victims), smugglers, criminal suspects, families of the suspects, lawyers, medical institutions, refugee and asylum seeker rights campaigners, and unspecified emoters (which are unknown or implicit). Triggers were not categorized since they were too diversified, but some of them would be mentioned in the analysis when necessary.

After manual annotation, the software provided the frequency of each type of affect resources and the frequencies of emoters under each type of emotion. Then, these basic data were used for comparative analysis.

\section{Results}

In this section, an overview of corpus findings will be presented first, followed by a detailed analysis of the relationship between affect and the emoters experiencing the affect. 


\subsection{Overview of corpus findings}

As shown in Figure 2, negative affect features significantly outnumber positive ones in the news reports about Chinese migrants in both tragedies. In the reports about the 2000 Dover tragedy where victims were Chinese, $41 \%$ of affect features are positive, 59\% of them negative ( $43 \%$ of affect are positive and $57 \%$ negative in The Guardian; 37\% of affect are positive and 63\% negative in The Times). In the reports about the 2019 Essex tragedy when victims were thought to be Chinese, $38 \%$ of affect features are positive, $62 \%$ of them negative ( $41 \%$ of affect are positive and 59\% negative in The Guardian; 32\% of affect are positive and $68 \%$ negative in The Times). However, in the news reports about Essex tragedy when victims were suspected or confirmed to be Vietnamese, more positive markers are exhibited than negative ones (positive markers account for $52 \%$ and negative $48 \%$ in The Guardian; positive markers make up 56\% and negative $44 \%$ in The Times).

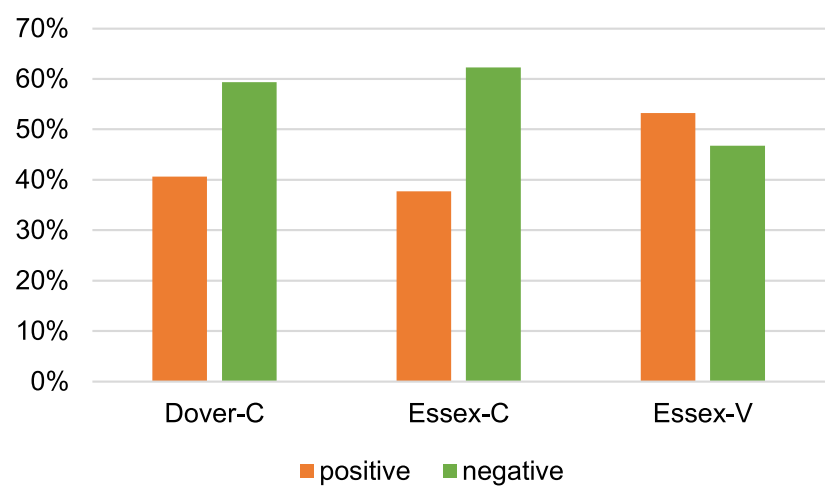

Figure 2: Distribution of positive and negative affect.

Figure 3 reveals similarities among the three folders: Firstly, dis/inclination markers take the most share. In the Dover-C folder, dis/inclination markers account for 52\% of affect (49\% in The Guardian, 55\% in The Times); in the Essex-C folder, dis/inclination markers make up $44 \%$ of affect ( $43 \%$ in The Guardian, $45 \%$ in The Times); in the Essex-V folder, dis/inclination markers make up 49\% of affect (46\% in The Guardian, 53\% in The Times). Secondly, dis/satisfaction markers occupy the least proportion. In the Dover-C folder, dis/satisfaction markers account for $7 \%$ of affect ( $8 \%$ in The Guardian, 4\% in The Times); in the Essex-C folder, dis/satisfaction markers take up 4\% of affect (5\% in The Guardian, $2 \%$ in The Times); in the Essex-V folder, dis/satisfaction markers make up $4 \%$ of affect (1\% in The Guardian, $8 \%$ in The Times). The difference among the three folders lies in that when victims were believed to be Chinese, in/security outnumbers un/happiness; when victims were suspected 
or confirmed to be Vietnamese, in/security is outnumbered by un/happiness. In the Dover-C folder, in/security markers occupy $26 \%$ while un/happiness markers take up $16 \%$ of affect (27 vs. $15 \%$ in The Guardian, 22 vs. $20 \%$ in The Times); in the Essex-C folder, in/security markers make up 35\% while un/happiness markers take up $16 \%$ of affect (32 vs. 17\% in The Guardian, 40 vs. 15\% in The Times); In the Essex-V folder, in/ security markers account for 19\% while un/happiness markers take up $28 \%$ of affect (22 vs. 32\% in The Guardian, 15 vs. $23 \%$ in The Times).

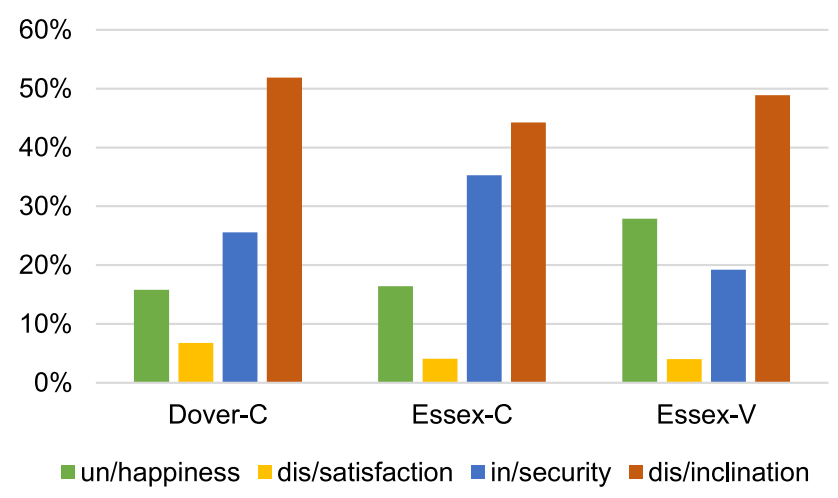

Figure 3: Distribution of four affect sub-systems.

Figure 4 demonstrates the distribution of affect features. It can be found that in the Dover-C folder, inclination (31\%), disinclination (21\%) and disquiet $(18 \%)$ occur most frequently; in the Essex-C folder, inclination (32\%), disquiet (20\%), surprise (16\%), disinclination (12\%) occupy the most proportion; in the Essex-V folder, inclination (40\%), misery (16\%), disquiet (15\%) and affection (11\%) account for the most proportion.

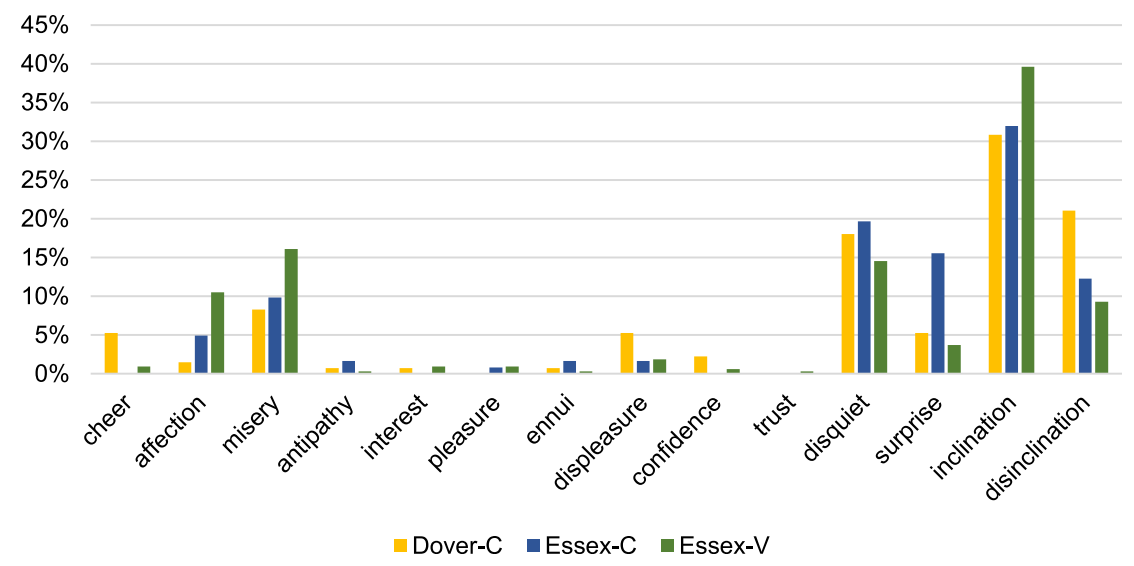

Figure 4: Distribution of affect features. 
Figure 5 shows the distribution of emoters across the three folders. It can be discovered that Western power elites occupy a large proportion in all of the three folders (25\% in the Dover-C folder, 23\% in the Essex-C and Essex- $\mathrm{V}$ folders). In the Dover-C folder, Western power elites, families of the victims, victims and other migrants are the emoters that occur most frequently; In the Essex-C folder, the frequencies of Western power elites, unspecified emoters, Western citizens and other migrants are higher than those of other emoters; In the Essex-V folder, families of the victims, Western power elites, victims and unspecified emoters occur more frequently than other emoters.

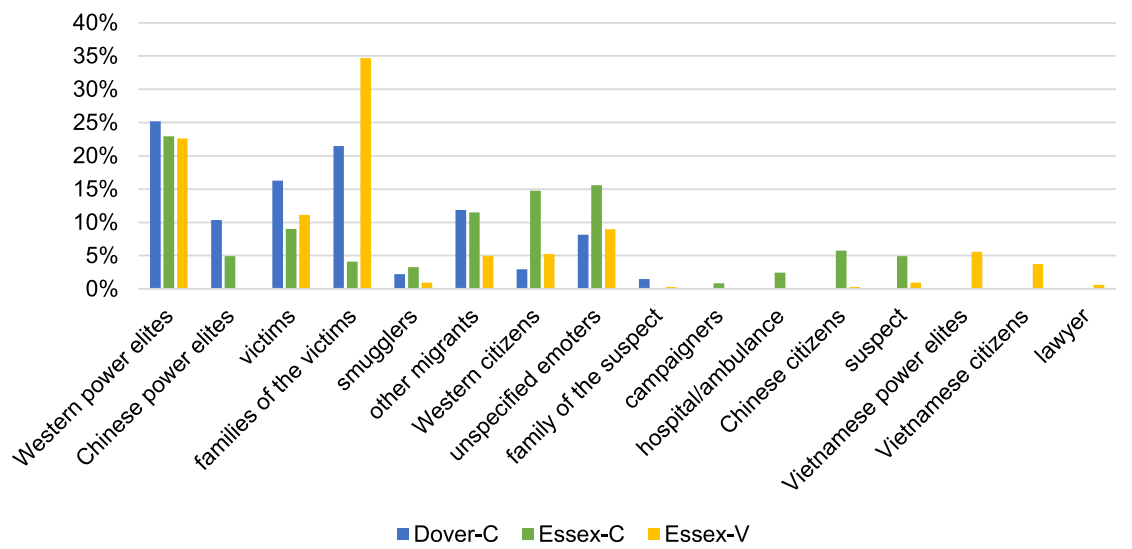

Figure 5: Distribution of emoters.

Figure 6 reveals differences between The Guardian and The Times in relation to distribution of emoters. In The Guardian, families of the victims occur most frequently (30\%), followed by Western power elites (22\%) and other migrants (10\%). In The Times, however, the pattern is different: of all emoters having experienced emotions, Western power elites account for $25 \%$, families of the victims $18 \%$, victims $16 \%$.

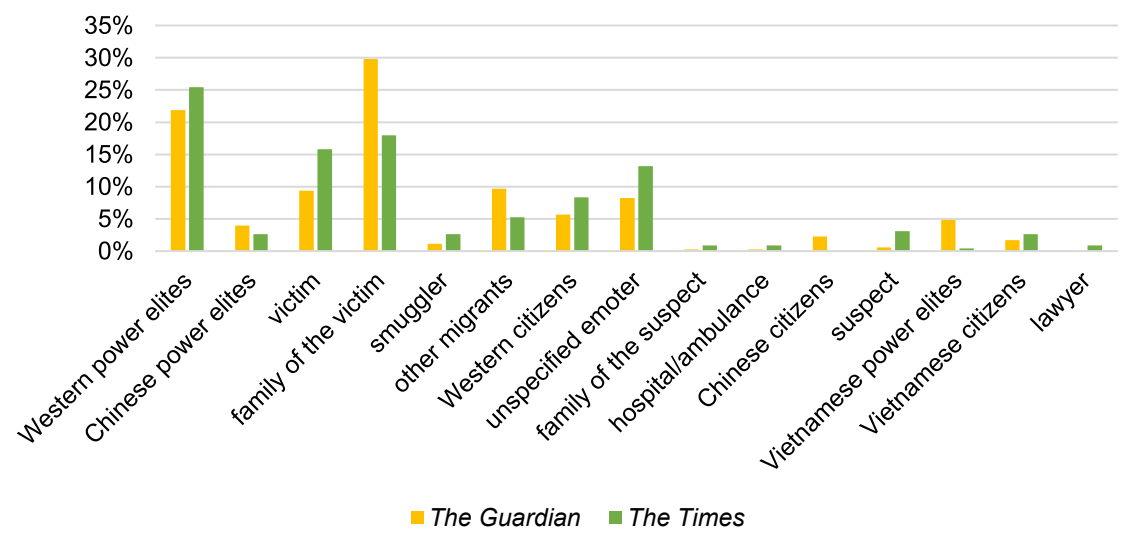

Figure 6: Distribution of emoters in The Guardian and The Times. 
To summarize, different patterns of affect were employed when victims were believed to be Chinese and when victims were believed to be Vietnamese. Firstly, the Essex-V folder contains more positive affect and less negative affect than the Dover-C and Essex-C folders; Secondly, the Essex-V folder contains more un/happiness and less in/security resources than the Dover-C and Essex-C folders; Thirdly, the Essex- $V$ folder contains more inclination and affection and less disquiet and disinclination resources than the Dover-C and Essex-C folders; Fourthly, Western power elites take the most share of emoters in both the Dover$\mathrm{C}$ and Essex-C folders, while families of the victims are the main emoters in the Essex-V folder. In addition, The Guardian and The Times present similar patterns in respect of the distribution of affect markers, but distribute emoters in different ways.

In the following sections, more details about the relationship between emotions and emoters will be analysed through illustrating specific examples.

\subsection{Patterns of dis/inclination}

In the Dover-C folder, inclination accounts for $31 \%$ of the affect. Among the emoters experiencing the emotion of inclination, Western power elites, families of the victims and other migrants occur most frequently.

As shown in examples (1) and (2), Western power elites' inclination is chiefly related to seeking help or cooperation. In both cases, British police ask the victims' relatives to come and help confirm the identity of the victims. Both cases indicate that British power elites take active steps while Chinese relatives acted passively after the tragedy happened.

(1) None of the victims' relatives have yet approached police, who have appealed for help identifying them. (The Guardian June 21, 2000)

(2) Detective Superintendent Dennis McGookin [...] "I would make an appeal to the Chinese community that if anyone is concerned that one of the victims may be one of their loved ones, I would ask them to contact the casualty bureau [...] (The Guardian June 21, 2000)

As demonstrated in examples (3) and (4), families of the victims' inclination is mainly related to verifying that their loved ones were among the dead, while other migrants' inclination is concerned with their desire to stay in Britain for a better future. 
(3) They are desperate to discover whether their sons, both called Lin, were among the 58 who died. (The Times June 21, 2000)

(4) He hopes to open a Chinese restaurant and bring his girlfriend to Britain [...] I hope that the British Government will accept us and let us stay.” (The Times June 21, 2000)

Disinclination makes up $21 \%$ of affect in the Dover-C folder, and Western power elites, families of victims and Chinese power elites occur more frequently than other emoters that experienced the emotion of disinclination.

Western power elites' disinclination is mainly manifested in the Home Office's reluctance to grant amnesty to those relatives who were living illegally in Britain, while families of the victims' disinclination is chiefly related to their reluctance to help identify the dead. By using these expressions, British journalists depicted Chinese people as uncooperative. Below are the examples of disinclination taken from the corpus.

(5) But despite appeals for help by agencies investigating the tragedy, the Home Office has refused to waive immigration legislation for any relatives of the victims who have entered the UK illegally. (The Guardian July 5, 2000)

(6) Relatives of the dead are reluctant to come forward because of their own legal status. (The Guardian July 5, 2000)

Inclination accounts for 32\% of affect resources in the Essex-C folder. Among all the emoters of inclination, other migrants (i.e. unspecified migrants, or migrants except victims) take the most share. Other migrants' inclination is still related to their desire to migrate to Britain.

The emotion of disinclination takes up $12 \%$ of affect resources, and it is mainly experienced by victims.

(7) “People don't choose death willingly," he added. "People don't put their lives in danger for no reason or purpose.” (The Times October 25, 2019)

Victims' disinclination is mostly related to their fear of death, their unwillingness to be smuggled into Britain, and their reluctance to be forced to do indecent jobs. As shown in example (7), the victims of the tragedy did not choose to die willingly; since they could hardly make a living in their own country, they had no alternative but to take this desperate measure.

The Essex- $V$ folder contains more markers of inclination ( $40 \%$ of affect) than the other two folders. The emotion of inclination is mainly experienced by Western power elites, families of the victims and Vietnamese power elites. 
Example (8) shows that Western power elites' inclination is chiefly related to British police's call for help and their desire to arrest the suspects. As shown in example (9), families of the victims expressed their wish to receive the intact bodies of the victims, showing their deep love for their relatives. Vietnamese power elites' inclination is related to their requirement for Vietnam's propaganda department. As presented in example (10), British journalists depicted the Vietnamese government as reluctant to report about repatriations of the victims.

(8) Ronan and Christopher Hughes are wanted on suspicion of manslaughter and people trafficking. Essex police said that they had spoken to Ronan Hughes by phone but the men were still at large. (The Times November 26, 2019)

(9) He said the government would rather bring back ashes post-cremation, but the families had all asked for the bodies to be returned intact. (The Guardian November 20, 2019)

(10) A blogger on Radio Free Asia revealed that Vietnam's propaganda department had written to newspaper editors asking them to "not report on identities or situations of families with suspected bereavement". (The Guardian November 20, 2019)

In short, British journalists showed their different attitudes toward China and Vietnam by using the emotion of dis/inclination. They manipulated Western power elites' inclination to invoke positive judgment upon Western power elites. When victims were believed to be Chinese, disinclination of families of the victims and Chinese power elites was utilized to invoke negative judgment upon Chinese people. In addition, inclination of other migrants invoked positive judgment upon the UK and negative judgement upon China. When victims were believed to be Vietnamese, inclination of Vietnamese power elites invoked negative judgment upon Vietnamese government. However, families of the victims' inclination was manipulated to invoke positive judgment upon them.

\subsection{Patterns of in/security}

In/security takes up $26 \%$ of affect resources In the Dover-C folder. The emotion of in/security is predominantly negative and is chiefly manifested in disquiet. 
Disquiet accounts for $18 \%$ of affect resources, and it is mainly experienced by emoters such as families of victims and victims. Disquiet of families of the victims involves their worries about their relatives and their worries about being deported, which emphasized their illegal status and invokes negative judgment ('veracity') on them. Example (11) is from Bobby Chan, a case worker at the Central London Law Centre, who said he had been contacted by one of the relatives. As presented in example (12), victims' disquiet is basically concerned with anxiety when they found it hard to breathe in the truck.

(11) "She was very concerned about talk of a major police investigation and was even worried about talking on the phone. She has just been granted exceptional leave to remain but she is worried that coming forward might endanger her status.” (The Guardian June 21, 2000)

(12) "They were shouting for assistance. They removed items, shoes and trainers, and were banging these on the container walls in an attempt to have themselves heard.” (The Times June 26, 2000)

In the Essex-C folder, in/security takes up 35\% of affect resources. Markers of in/ security are predominantly negative.

Disquiet accounts for $20 \%$ of affect resources and it is chiefly experienced by victims and British citizens. Victims' disquiet is mainly triggered by their fear for death. In example (13), a survivor of a similar event said he had been experiencing the emotion of disquiet even long after his dreadful experience. As shown in example (14), British citizens' disquiet is mostly related to their concerns about lax security after they found groups of migrants being loaded from lorries into coaches and minibuses.

“The screams of these people still haunt me," Ahmad al-Rashid, a Syrian refugee, said. "I can never forget that moment when I touched death while being kept in the back of the freezer lorry." (The Times October 25, 2019)

Despite reporting the incidents to police, locals claim that the authorities failed to act on their concerns about lax security around the port. (The Times October 24, 2019)

Surprise accounts for $16 \%$ of affect resources, and the emoters experiencing surprise are mainly Western and Chinese citizens, and one of the suspects. Western and Chinese citizens' surprise is chiefly related to their disbelief that such a tragedy happened. Example (15) is said by a neighbor of the two suspects, Thomas and Joanne, and example (16) shows Chinese citizens' reaction to the tragedy.

(15) "I am very shocked but we don't know the truth of it all yet. I know that Joanne has said that she sold the cab, so who knows?” (The Guardian October 25, 2019) 
(16) The news occupied three of the top 10 most discussed topics on Weibo, with internet users expressing confusion and disbelief. (The Guardian October 25, 2019)

The Evening Standard reported that, having driven to a nearby industrial park, Mr Robinson passed out from the shock of discovering the 39 dead bodies frozen in the lorry. (The Times October 29, 2019)

The suspect's surprise is basically concerned with his shock when finding the 39 migrants in the lorry dead, as shown in example (17).

The emotion of in/security in the Essex- $V$ folder occurs less frequently than that in the other two folders. Most in/security resources are manifested as the emotion of disquiet, which is mainly experienced by Vietnamese families who worried that their loved ones were among the dead.

In short, when victims were believed to be either Chinese or Vietnamese, insecurity of families of the victims was presented to indicate their love for their relatives, invoking positive judgment upon families of the victims. However, when victims were believed to be Chinese, families of victims' insecurity was also utilized to emphasize their illegal status, invoking negative judgment upon them. In addition, when victims were believed to be Chinese, insecurity of victims, Western and Chinese citizens were utilized for arousing sympathy; insecurity of Western citizens was presented to emphasize the illegal status of Chinese immigrants, invoking negative judgment upon Chinese people.

\subsection{Patterns of un/happiness}

In the Dover-C folder, un/happiness takes up $16 \%$ of affect resources. The emotion of happiness is mainly manifested as cheer, which is chiefly experienced by smugglers and other migrants. Smugglers' cheer is basically related to the lawlessness in the area and the profits brought by smuggling migrants. By describing smugglers' cheer about breaking the law, British journalists invoked negative judgment upon them. Other migrants' cheer is mainly triggered by their journey to a better life. Below are the examples of happiness taken from the corpus.

(18) Exulting in this isolation and lawlessness are the snakeheads, the smuggling gangs. (The Guardian June 24, 2000)

(19) Propped in a bar two months ago, Ilyr, a veteran smuggler, grinned when explaining his preference for the Chinese. "They're smaller and lighter. You can fit 60 of them for 40 Kurds or Romanians." (The Guardian June 24, 2000) 
(20) Film footage of the Chinese immigrants taken by a Belgian TV station shows a smartly dressed group of young people, occasionally smiling, and chatting to each other. (The Guardian June 22, 2000)

Negative affect is mainly manifested as misery, which is experienced by different emoters, including Western power elites, victims, family of the victims, other migrants, and family of the suspect. Unsurprisingly, their misery is triggered by the tragic event, eliciting sympathy from the readers. Example (21) presents a distressed woman who feared that her relative was among the dead; example (22) introduces the condition of the two surviving victims.

(21) "She called me when the news broke very distressed and asking if there was a way of checking the identities [...]" he said. (The Guardian June 21, 2000)

(22) Two young men survived the journey [...] They had been under police protection at the Kent and Canterbury hospital in Canterbury, where they were treated for severe dehydration and trauma. (The Guardian June 23, 2000)

In the Essex-C folder, un/happiness accounts for $16 \%$ of affect resources. The emotion of happiness is chiefly manifested as affection, which is mainly experienced by smugglers. As presented in example (23), smugglers show affection for a certain route of transporting immigrants. The emotion of unhappiness manifests itself as misery, which is mainly triggered by the tragic event and experienced by Western citizens (see example (24)).

(23) Border inspectors warned ministers two years ago that the route was being favoured by people-traffickers. (The Times October 24, 2019)

(24) People are devastated but also stunned and shocked that someone local has been arrested.” (The Guardian October 25, 2019)

The Essex-V folder contains more markers of un/happiness than the other two folders. Both negative and positive markers of un/happiness occupy a large proportion of affect resources. Markers of misery take up $16 \%$ of affect, and the emotion of misery is mainly experienced by victims, the family members of the victims, and Vietnamese citizens. Victims' misery is mainly triggered by the failure of their migration plan and their forthcoming deaths. Families of the victims' misery is mainly triggered by the deaths of the victims. Below are the examples of misery selected from the Essex-V folder. 
(25) “I'm sorry Mum. My journey abroad hasn't succeeded.” (The Guardian November 8, 2019)

(26) Tu's mother, Nyuyen Dinh Sat, lay on a mat before the altar, sobbing [...] Sat cried out, reaching desperately for the picture of her son [...] She collapsed into tears, with pleas of “son, son". (The Guardian October 27, 2019)

Markers of affection take up $11 \%$ of affect resources, and the emotion of affection is basically experienced by families of the victims. Their affection is chiefly concerned with their deep love for the victims. As shown in example (27), victims are referred to as "loved ones". Families' deep love for the victims is contrasted with their misfortunes, eliciting sympathy for them from readers. Unsurprisingly, Vietnamese citizens' misery is triggered by the deaths of their compatriots, as displayed in Example (28). And the emotion of misery also leads readers to sympathize with these emoters.

(27) It also says that under Vietnamese law, the cost of repatriating corpses or ashes of loved ones must always be covered by the family, not the government [...]. (The Guardian November 20, 2019)

(28) Nguyen Hoang Ton [...] said that the entire Vietnamese diaspora in Britain had been upset by the deaths. (The Times November 4, 2019)

In short, whether victims were believed to be Chinese or Vietnamese, British journalists manipulated unhappiness to elicit public sympathy. The difference lies in that when victims were believed to be Chinese, smugglers' happiness was utilized to invoke negative judgment upon them; when victims were believed to be Vietnamese, families of the victims' happiness was used for invoking positive judgment upon them.

\subsection{Patterns of dis/satisfaction}

Dis/satisfaction takes the least share among the four main categories of affect across the three folders. However, The Dover-C folder contains more markers of dis/satisfaction than the other two folders. Given the low frequency of markers of satisfaction, a comparative analysis of satisfaction is excluded from this article. Dissatisfaction is mainly experienced by Western power elites and Western citizens. 
(29) Police complain that their contacts have gone to ground. Fewer Chinese faces were on the streets [...]. (The Guardian June 24, 2000)

(30) Weeks after the first two arrived a trickle of other Chinese people appeared and within 48 hours the number increased dramatically. Eventually local residents complained to the authorities. (The Guardian June 22, 2000)

As shown in the examples above, Western power elites' dissatisfaction is concerned with the non-cooperation of Chinese people, invoking negative judgments upon Chinese; Western citizens' dissatisfaction is triggered by their discovery of Chinese people around their residences, showing their intolerance for Chinese illegal immigrants.

\section{Discussion}

From the corpus findings presented above, we have found similarities and dissimilarities in the way emotions are displayed in different folders. The similarities lie in that markers of dis/inclination take the most share of affect in all folders, and markers of dis/satisfaction account for the least proportion of affect. In addition, Western power elites are given many opportunities to speak out in the news reports.

Differences between the folders containing reports about Chinese migrants and the folder containing reports about Vietnamese migrants are remarkable.

Firstly, in the Dover-C folder and the Essex-C folder, negative markers of affect significantly outnumber positives ones. By contrast, in the Essex- $V$ folder, more positive markers of affect are displayed than negative ones. Secondly, markers of in/security outnumber those of un/happiness in the Dover-C and Essex-C folders, while the pattern is the opposite in the Essex- $\mathrm{V}$ folder.

Whether in the Dover-C folder and the Essex-C folder or the Essex- $\mathrm{V}$ folder, inclination of British power elites is concerned with their desire of seeking help (e.g. British police appealed for help identify the victims) and arresting the criminal suspects (e.g. the suspects were wanted by British police). In the Dover-C folder and the Essex-C folder, inclination is concerned with the desire of other migrants to leave China and migrate to the UK, and disinclination is related to the reluctance of families of the victims and Chinese power elites to cooperate (e.g. families of the victims were unwilling to come to help identify the victims for fear of deportation to China). In the Essex-V folder, inclination is related to the reluctance of Vietnamese power elites to report about repatriations of the victims, and the desire of families of the victims to receive intact bodies of their loved ones. In a word, positive 
judgment is invoked upon British power elites and families of Vietnamese victims while negative judgment is invoked mainly upon China and Chinese people.

In/security is presented differently in different folders. In the Dover- $C$ and the Essex-C folders, insecurity is related to families of the victims' illegal status in the UK (e.g. one of the relatives is worried that coming to help identify the victims might endanger her status in the UK), their love for their relatives, victims' worries about death, and Western and Chinese citizens' shock triggered by the tragedy. However, in the Essex-V folder, insecurity is basically related to families of the victims' love for the victims (e.g. families worried that their loved ones were among the dead). In short, British journalists intended to make many positive judgments about Vietnamese families and a large number of negative judgments about Chinese families.

Unhappiness is concerned with misery triggered by the tragedies (e.g. the mother of a victim collapsed into tears when hearing the news), whether in the Dover-C folder and the Essex- $\mathrm{C}$ folder or the Essex- $\mathrm{V}$ folder. In the Dover- $\mathrm{C}$ folder and the Essex-C folder, happiness is mainly related to smugglers making profits through illegal means (e.g. smugglers preferred Chinese migrants because of their low weights); in the Essex-V folder, happiness is chiefly concerned with the families' deep love for their relatives (e.g. victims were called "loved ones" by their families). In short, readers' sympathy is aroused through presenting misery; negative judgement is invoked upon smugglers; positive judgment is invoked upon Vietnamese families.

The Dover-C folder contains the most dis/satisfaction markers among the three folders. Dissatisfaction is concerned with police's complaints about the noncooperation of Chinese people and Western citizen's intolerance for Chinese illegal immigrants found in their residential area. In a word, British journalists used Westerners' dissatisfaction with Chinese people to create a negative image of China.

The corpus findings also show that The Guardian and The Times present similar patterns in terms of the distribution of affect markers. However, the two newspapers distributed emoters in different ways. The Guardian gave more voice to families of the victims compared with The Times, while The Times exhibited more markers of affect of victims than The Guardian. Families of the victims' emotions are mainly triggered by their deep love for their relatives, while victims' emotions are mainly triggered by their unsuccessful journey to immigrate into Britain. It seems that The Guardian displayed families' emotions to invoke sympathy upon them, while The Times exhibited victims' emotions to show the bad consequence brought by attempts of illegal immigration. 
The different patterns of emotion in reports about Chinese and Vietnamese reveal that British journalists held different attitudes toward China and Vietnam. The findings verify that news discourse is permeated by structures, institutions and values from outside the newsroom, such as economy, politics and ideology (Richardson 2007) and that news journalists cannot escape the fact that they are tied to a broader social system (Shoemaker 1991).

Both The Guardian and The Times are serious newspapers, the readership of which mainly consist of politicians, elites and intellectuals, who are concerned about domestic politics, economy and international relationships. The Guardian is a left-wing newspaper, which stands for the interests of liberal middle-class Britain, while the political leaning of The Times is central-right (Oxford Royale Academy 2016). Despite the different political inclinations, both of the two newspapers represent political parties of the bourgeois and defend British interests.

The ideological contradiction between Britain and China influenced how British journalists covered China. The ideological differences between China and Britain lead to British cognitive bias toward China. In 1950, Britain, considering its interests in China, admitted the People's Republic of China as the legitimate government of China on the one hand, and claimed that it would not change its long-term goal shared with the US, i.e. to oppose communism on the other hand (Lan and Luo 2013). British journalists described China in the Dover-C folder as a poor and backward country. In 2019, the Essex migrant tragedy happened not long after the mass protests against the proposed extradition bill in Hong Kong. Against this background, Britain's ingrained distrust toward the Chinese government and its belief that Britain has duty and moral obligations to safeguard Hong Kong's future were manifested (Liu and Jiang 2019). Therefore, it was not surprising to find that British journalists seized every opportunity to invoke negative judgements upon China even when the nationality of the victims in the Essex migrant tragedy was yet to be confirmed. This supports the idea that when ideologies are mapped onto discourse, they typically become expressed in terms of their own underlying structures, such as the polarization between positive ingroup description and negative outgroup description (van Dijk 2006).

Britain's desire to sustain its great power status in the world also exerted an influence on how Britain perceived China and how British journalists covered China (Lan and Luo 2013). 2019 marked the 70th anniversary of the founding of the People's Republic of China, which highlighted great achievements in all aspects of Chinese society, especially economy. In hope of sustaining the existing global political pattern, British journalists used news media to defame China when an opportunity came, i.e. the Essex migrant tragedy. Since Vietnam is a small developing country, which can hardly play a role in influencing the power status of 
Britain, the British news reports in the Essex- $\mathrm{V}$ folder are relatively objective: the positive and negative affect resources are relatively equally distributed.

\section{Conclusion}

This article investigates British journalists' different attitudes toward China and Vietnam by examining emotion patterns in British news reports about the Dover and Essex tragedies. Negative affect resources found in the news reports about China are more than those in the coverage about Vietnam. British journalists mediated emotions to represent China, whether in 2000 or 2019, as a backward and underdeveloped country where citizens risked their lives to escape to Britain, a developed country. However, in the Essex migrant tragedy, when the victims were found to be Vietnamese instead of Chinese, British journalists shifted attention to the pitiful Vietnamese families of the victims and manipulated emotions to arouse readers' sympathy. The corpus findings can be attributed to ideological contradiction between Britain and China, Britain's distrust toward China's system, and Britain's concern about its great power status around the world.

This study proves the great power of Appraisal System to explain news discourse and verifies that news discourse is penetrated with ideology, politics, and economy. However, the limitation lies in that only affect has been examined in news discourse. More efforts can be made to employ judgment and appreciation to explore British journalists' different attitudes toward immigration from different countries.

Acknowledgments: I would like to convey my sincere gratitude to Professor Wang Zhenhua for his valuable suggestions on the structure and content of the article. I also want to extend my special thanks to Associate Professor Huan Changpeng for his insightful suggestions on choosing this research project and collecting data. The author assumes responsibility for any remaining errors.

\section{References}

Blinder, Scott. 2015. Imagined immigration: The impact of different meanings of 'Immigrants' in public opinion and policy debates in Britain. Political Studies 63(1). 80-100.

Blinder, Scott \& William L. Allen. 2016. Constructing immigrants: Portrayals of migrant groups in British national newspapers, 2010-2012. International Migration Review 50(1). 3-40.

Brader, Ted, Nicholas A. Valentino \& Elizabeth Suhay. 2008. What triggers public opposition to immigration? Anxiety, group cues, and immigration threat. American Journal of Political Science 52(4). 959-978. 
Cheregi, Bianca Florentina. 2015. The discursive construction of Romanian immigration in the British media: Digitized press vs. television documentaries. Romanian Journal of Communication and Public Relations 17(2). 54-73.

Citrin, Jack, Donald P. Green, Christopher Muste \& Cara Wong. 1997. Public opinion toward immigration reform: The role of economic motivations. The Journal of Politics 59(3). 858-881.

Dustmann, Christian \& Ian P. Preston. 2007. Racial and economic factors in attitudes to immigration. The B.E. Journal of Economic Analysis \& Policy 7(1). 1-39.

Düvell, Franck. 2011. Irregular immigration, economics and politics. CESifo DICE Report 9(3). 60-67. https://www.cesifo-group.de/ifoHome/publications/docbase/details.html? docld=16752111 (accessed 25 January 2020).

Gamson, William A. \& Andre Modigliani. 1989. Media discourse and public opinion on nuclear power: A constructionist approach. American Journal of Sociology 95(1). 1-37.

Gavin, Neil T. 2018. Media definitely do matter: Brexit, immigration, climate change and beyond. The British Journal of Politics and International Relations 20(4). 827-845.

Hatton, Timothy J. \& Stephen Wheatley Price. 2005. Migration, migrants and policy in the United Kingdom. In Klaus F. Zimmermann (ed.), European migration: What do we know? 113-172. Oxford: Oxford University Press.

Huan, Changpeng. 2017. The strategic ritual of emotionality in Chinese and Australian hard news: A corpus-based study. Critical Discourse Studies 14(5). 461-479.

Igartua, Juan-José \& Lifen Cheng. 2009. Moderating effect of group cue while processing news on immigration: Is the framing effect a heuristic process? Journal of Communication 59(4). 726-749.

Lan, Jie \& Rong Luo. 2013. Yingguo zhuliu meiti dui zhongguo xingxiang de renshi [The image of China in British mainstream media]. Hubei Shehui Kexue [Hubei Social Sciences] (8). 185-188.

Liu, Ming \& Cong Jiang. 2019. Constant fear, but lingering nostalgia: British press representations of post-colonial Hong Kong 20 years on. Discourse \& Communication 13(6). 630-646.

Marcus, George E., John L. Sullivan, Elizabeth Theiss-Morse \& Daniel Stevens. 2005. The emotional foundation of political cognition: The impact of extrinsic anxiety on the formation of political tolerance judgments. Political Psychology 26(6). 949-963.

Martin, James Robert \& David Rose. 2007. Working with discourse: Meaning beyond the clause. Beijing: Peking University Press.

Martin, James Robert \& Peter Robert R. White. 2005. The language of evaluation: Appraisal in English. Basingstoke: Palgrave Macmillan.

McLaren, Lauren, Hajo Boomgaarden \& Rens Vliegenthart. 2018. News coverage and public concern about immigration in Britain. International Journal of Public Opinion Research 30(2). 173-193.

Oxford Royale Academy. 2016. Black and white and read all over: A guide to British newspapers. https://www.oxford-royale.co.uk/articles/a-guide-to-british-newspapers.html (accessed 7 October 2020).

Richardson, John. 2007. Analysing newspapers: An approach from critical discourse analysis. New York: Palgrave Macmillan.

Sally, Wehmeier (ed.). 2005. Oxford advanced Learner's dictionary, 7th edn. Oxford: Oxford University Press.

Shoemaker, Pamela. 1991. Gatekeeping. London: Sage.

Song, Quancheng. 2008. Yingde feifa yiming shehui wenti zhi bijiao yanjiu [A comparison of the social problems concerning illegal immigration in Britain and Germany]. Ouzhou Yanjiu [Chinese Journal of European Studies] 26(5). 109-124. 
van Dijk, Teun A. 2006. Ideology and discourse analysis. Journal of Political Ideologies 11(2). 115-140.

$\mathrm{Xu}$, Xiaohong. 2018. Yingguo yiming duoyuan wenhua zhuyi zhengce shulun [On multiculturalism in immigration of the United Kingdom]. Harbin Gongye Daxue Xuebao (Shehui Kexue Ban) [Journal of Harbin Institute of Technology (Social Sciences Edition)] 20(4). 14-20. 